\title{
IMPOSED STALINISM: NARRATING RĪGA'S URBAN SPACE THROUGH SOVIET FILMS FROM 1945 TO 1953
}

\section{Īstenotais staḷinisms: Rīgas atveids padomju perioda filmās no 1945. līdz 1953. gadam}

\author{
Jānis Matvejs \\ University of Latvia, Faculty of Geography and Earth Sciences \\ janis.matvejs@gmail.com
}

\begin{abstract}
Cinema is essentially a geographic art, a way of "writing the world". By bringing a geographic perspective to examining how cinema evokes a location, we gain a better understanding of the way we socially construct place/location in our geographical imaginations. Studies of films can inform us about new historio-graphical perspectives on space, architecture and urban imagery, and thus advance new critical insights into the geo-historical formation of urban modernity.

The focus of this study is to describe the portrayal of Rīga's urban space under Stalin's regime. The mixed method approach is used to interpret the representation of Stalin's Soviet occupied Rìga. This exposes different elements and processes about the formation of Soviet Rìga's cinematic landscape. Spatial analysis of Stalin's Rīga not only displays which sites were transformed in cinematic places but also acts as an archaeological tool that explores hidden residential settings during the Soviet period.

This study sheds light on innovative methods in historical analyses of geographical thought and practice, where films have been considered as geographic practice for visual language with a goal to evoke viewer experiences of inhabiting Soviet urban space. This paper acknowledges both development and spatial organization of urban space in Stalin's Rīga, and that politically restricted space uncovers gaps and contradictions in the official Soviet history by creating an alternative history of Soviet Rìga.
\end{abstract}

Keywords: cinema, Soviet Rīga, representation, apartment, visual methodology

\section{Introduction}

Landscape as text is the dominant metaphor in film geography because it provides a means by which to explore the intersection between the narration of films and geography (Lukinbeal 2005). In studying cinematic landscape, acknowledgment of cultural values and historical background of the geographical location is important, and allows us to understand and interpret a place of residence (Kennedy and Lukinbeal 1997). The interest of Geographers in film arose simultaneously from two streams of thought: humanism and socio-cultural studies (Kennedy and Lukinbeal 1997). The central property that has been reviewed in geographical studies of cinema, is the transformation of the location's look/appearance (Lukinbeal 2012), which allows the viewer to suspend belief and accept that a narrative is taking place in a particular locale.

The era of Stalin was a time of profound change for the people of the Soviet Union. Cities were transformed into new urban conglomerations that bore the mark of socialist planning and Soviet ideological theories of urban living. Industries were created and new towns established where none had existed before. The Stalin era Rìga experienced economic and political transformations through the deconstruction of specific urban structures, such as churches. There was also some reconstruction and 
remodelling of the historical buildings that were in the best repair. Some new monuments and enormous expansion of factories appeared, that changed Rìga from being city of merchants into a city of workers. New transport lines and bus routes reached out to these new industrial areas.

In a study of Soviet history and design, historian Susan Reid found that the reflection of domestic life has hardly been the dominant angle from which to study the Soviet Union (Reid 2009). Neglect of human comfort, shortage of living space and redesign of urban structures were some of the questions/issues that were hidden from the official ideology but coded into films. Thus, this study investigates how living spaces were depicted in the films of the Stalin era and interprets the discourse on residential areas of Rīga. A cinematic analysis of Latvian documentary and fiction movies unfolds the spatial realities of Soviet Riga where the city is transformed not only through new construction unities, but also by celebratory events and everyday people.

\section{Data and methods}

To better understand the subject, an advanced research approach was developed that exposes various processes about the formation of Soviet Riga's cinematic landscape under Stalin's regime. The research consists of a qualitative visual approach that offers an effective and critical way of describing city-space, as well as of quantitative analysis that allows us to examine the similarities and disparities of urban landscape. Spatial analysis of Soviet Rīga displays which sites were transformed in cinematic places and acts as an archaeological tool that explores hidden urban settings during the Soviet period.

276 films from 1945 through 1953 were randomly selected for this study. The data about films was collected using the database of the National Film Centre of Latvia. Content analysis of films was accomplished in which each film was divided into 5minute intervals (Hazan 1997). Grouping video materials allowed for the possibility to review represented urban structures in more detail. Secondly, each sequence was described by reference to eight indicators, based on previous research about Stalin's housing (Reid 2006; Reid 2009): geographical location, social description, furnishing, appliances, representation of public or semi-public space, mise-en-scène, actor's monologue or dialogue, and filming techniques used.

The analysis of cinematic content of two genres - fiction (2 films) and documentary (274 films) - consisted of a comparison of films with actual urban processes and development of housing. The films were divided into twelve categories depending on their geographical and functional structure, including natural objects, residential areas, street-level, industries, engineering constructions, recreational areas, cultural and religious structures, transportation system and others. In total, 601 spatial points were identified and mapped into the film analysis.

The mapping and analyses of the filmed sites reveals a stratigraphy of texts written across residential living spaces in Stalin's Rīga. Collected quantitative data was stored in a spatial database (QGIS software) to employ methods of geographical 
information systems on analysing and visualization of data. Various methods of geographical information systems, including cartographical approach, data frequency applying approach and spatial auto-correlation, were used to acquire more precise and data-based results.

\section{Results}

Stalin brought an end to the state-sanctioned debate among modernists on the future of the socialist city. Accordingly, ongoing series of Five-Year Plans accelerated urbanization and industrialization throughout Soviet-occupied Latvia. City-planning was considered as an essential alternative to chaotic capitalist development, with the potential to meet the needs of the urban population. Consequently, a comprehensive master plan was released in 1945, with a focus on post-war reconstruction, housing, military complexes, industry, transportation, and public green space (Bunkše 1979; Hurina 2015).

Another symbol of Soviet power under Stalin's regime was the naming and renaming of streets and institutions on behalf of major politicians or events (L,enina street, Komunāru square and others) (Grava 1993). The plasticity, verticality, symmetry and hierarchy of forms and functions of architecture were accomplished during the Stalin government years (Varga-Harris 2008), however the time-frame during which an attempt to implement Stalinist stylistics in architecture in Latvia took place was just too short. In many cases, it was either organically synthesised with local features, or introduced as a foreign body (Rudovska 2012).

Housing for residents remained insufficient, as elites were given apartments in the city (Gentile and Sjöberg 2006). Basic human needs were neglected in favour of industrial development and an image of grandiosity and the unwanted/less desirable social classes were excluded through urban design (Bodenschatz 2014; Gentile and Sjöberg 2010; Varga-Harris 2015). The highest social status residents stayed in the city centre, while workers lived on the outskirts of the city. Also, new residential developments tended to follow a kvartal model, in which buildings were bound by a city block with shops at street level and shared interior courtyards (French 1995; Reid 2006; Richardson 2010). However, the massive construction of residential housing was not possible, and housing revealed high building costs with outdated design solutions, limitation of construction management and inadequate technical equipment (Grava 1993; Hurina 2015).

The purpose of socialist realism was to limit cinematic representation to a specific and highly regulated faction of creative expression that promoted Soviet ideals. Cinematic representation of landscape during the Stalin period was limited by rigid censorship. More attention was paid to the spoken text in films. Consequently, certain ideas were easier to put to the public through images, dialogue and cinematic narrative (Mazierska 2014). Throughout the period of Stalin's regime, cinematic representation of both urban and rural areas is passive and distracted from the main cinematic character. Films do not reveal genuine urban space, but cities are portrayed rather from above or at 
a distance, idealizing the space and prohibiting arbitrary representation of dwellings (Näripea 2004).

Stalin period films are characterized by an idea of utopia (Prokhorov 2011). A great number of films from this period interpret heroic scenes of World War II. Cinema supports the main policy of Stalin's regime of the 1940s, rejection of the class struggle within the country and declaration of the creation of the united Soviet people, who had no ethnic, national, race or class problems. Living space in the cinema is depicted as monotonous, continuing Stalin's artificial grand style with submissive crowds and enormous buildings (Matvejs 2017). Genre modification of this period: generally, a war or historical drama and news-reel (Federov 2015).

Rìga's city-space in the cinema between 1945 and 1953 is depicted as monotonous and detached from the main character. The main themes of analysed films are concerned with the new political system, industrial achievements, residential routine and acquisition of rural landscape. Both fiction films (Dēli - Ivanovs 1946; Mājup ar uzvaru - Ivanovs 1947) interpret heroic scenes from World War II by using realistic scenes in showing everyday life. The intention to maintain a national identity is depicted by the representation of activities that are taking place in the countryside. News-reels from this period tend to support the main policy of Stalin's regime, rejection of the class struggle within the country and a declaration of the creation of the united Soviet people.

The main functional structure (18\% of spatial points) represented in films is the recreational area that includes outdoor recreational zones, such as parks and forests (Mežaparks, Šmerlis), or outdoor sports venues (Dinamo stadium) (Figure 1). Politically, the individual function of providing recreation was not considered as being genuinely socialist (Nuga 2016). However, for the socialist system these areas form a way of promoting healthy and entertaining leisure time after work. The reproduction of recreational areas in films was particularly increasing in 1950. Representation of these zones correlated also with the increase of and depiction of industries in films. Thus, depiction of these areas was becoming a cinematic guide to show citizens how to fill their free time after a day of hard work.

The second most depicted geographical structure (14\% of spatial points) in films is Rīga's street-space with two major roads - Brīvības street and Kr. Valdemāra street. In most films, both streets are depicted from above or at a distance in order to underline the broad structure and ability to hold large numbers of people. The representation of these streets is used as a propaganda gimmick. They are wide enough to hold a public demonstration that exemplifies worker solidarity, technological achievements and military might. In 12 films, Kr. Valdemāra street is depicted as being the central axis by which the workers go to Victory square where the military parade is being held. Depiction of streets is complemented by ideological texts such as "On a sunny morning in May, hundreds of thousands of people fill the streets and boulevards of Riga" (Padomju Latvija Nr. 17 - Jevsikovs 1951). 


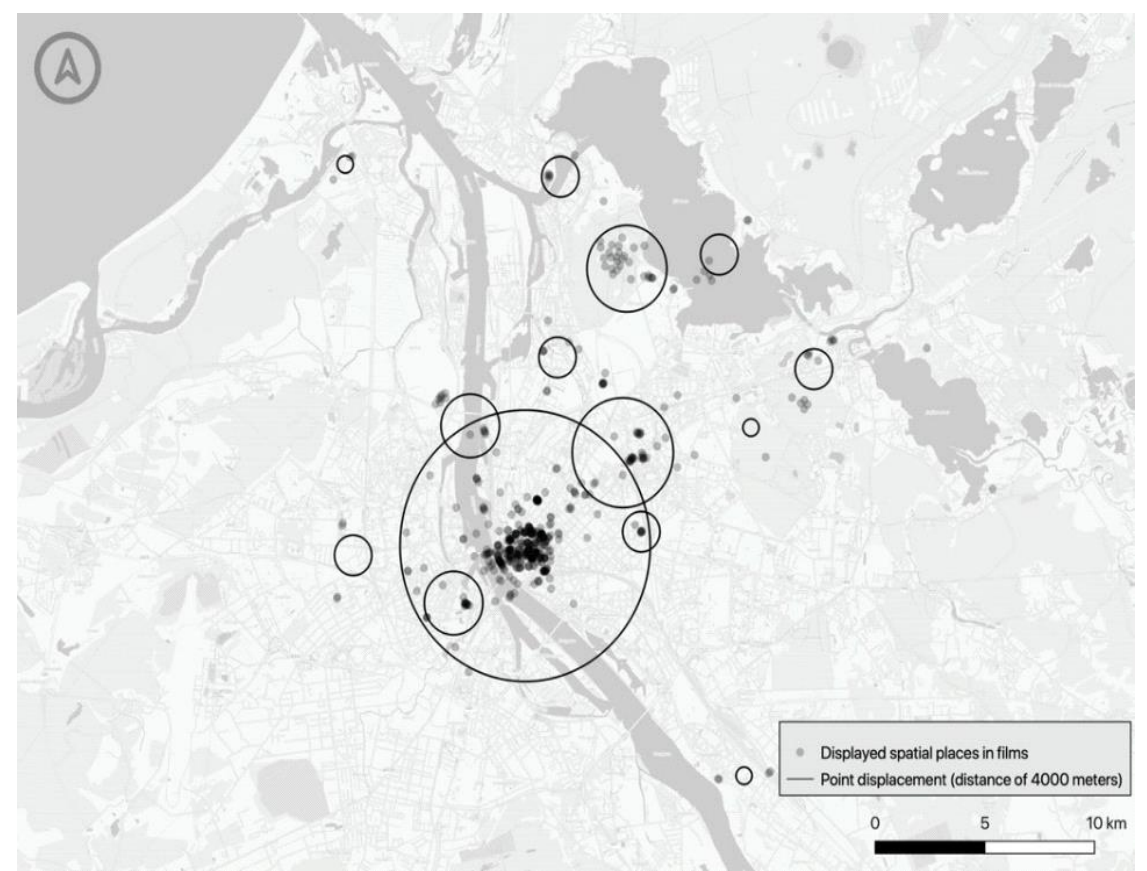

Figure 1. Represented geographic locations in films between 1945 and 1954 (author's figure)

Another important spatially functional group that is portrayed in films is the growing industrial sector (14\% of spatial points), including VEF, RER, the textile factory in the Jugla area and other factories. Initially film-makers represented construction sites (Rīga Shipyard) and light industry (the Chocolate Factory "Laima" or Jaunciems Paper Mill), but starting with 1948 the depiction of machinery, consumer electronics and textile industry had increased. Cinematic scenes with industrial zones are complemented by an ideological text about achievements of the workmen: "The "Red October" factory team already completed its annual plan in October this year" (Padomju Latvija Nr. 47 - Goldberga 1946). Factories in films were being glorified by focusing cinematic attention on the new technologies and methods used in various industries.

The growth of industries also contributed to the representation of residential structures. Between 1946 and 1953 seventeen films portrayed the construction of four to five-story residential apartment buildings. Each film emphasized the necessity of apartment allocation for industrial workers. In news-reels apartment scenes are characterized by spoken text that highlights anniversaries and the accomplishments of Five-year plans. For example, in Padomju Latvija Nr. 16 (Čardinina 1948) the building process is being idealized: "the first 56 apartments will be ready on the day of The Anniversary of the Great October Socialist Revolution".

Other major geographical and functional structures depicted in films include: administrative buildings (7\% of spatial points), public squares (7\% of spatial points), culture facilities ( $7 \%$ of spatial points), historical objects (6\% of spatial points), panoramic views of the city ( $6 \%$ of spatial points), educational institutions ( $6 \%$ of spatial points) and economic zones ( $6 \%$ of spatial points), such as the harbour or the 
Central market. Rīga's cinematic representation under Stalin's regime does not seek to reveal public service facilities (hospitals, fire brigades, police) or religious institutions. Since 1952, more foreign-states appear in films: Kolkhoz in Azerbaijan, Opening of the Volga-Don canal, whaling in the Bering Sea and other scenes.

\section{Conclusion}

This study set out to determine the manner and practices of representing the city space of Riga under Stalin's regime. The study has revealed that between 1945 and 1953 the representation of Riga is central with major geographical structures being the Old Town and parts of the city between Elizabetes and Tallinas streets. Outside the central part of the city, in most cases the films depict industrial and recreational areas. This idea exemplifies that socialist realism depicted reality of imagination: focusing on industrial areas in combination with recreational zones. Another visual aspect of Stalin's urban symbolism represented in films is the use of large public squares (Uzvaras laukums and Esplanāde), where it was possible to gather people and hold parades. However, various substantial public service facilities were ignored in official representation due to the limited resources and shortcomings in these structures.

The analysis of films has shown that negativity was not permitted in urban representation under Stalin's regime. Instead, sentiment about flawless living standards was created, by presenting common images. Cinematic representation of city-space in Stalin's period is characterized by an artificial utopia. For instance, representation of Stalinist-era apartments with mono-functional and spatially discreet rooms, focusing on the family dining table or stolovaia at the centre that expressed a petit-bourgeois layout (Padomju Latvija Nr. 41 - Šulatins 1952). The landscape is static and detached from the hero becoming as a pictorial background. The films also emphasise that from 1945 there was a strong tendency to talk about preliminary industrialization plans and to gradually prepare for mass production.

The most obvious finding to emerge from this research is that city-space is frequently depicted in films, thus becoming an integral part of visually represented space during Stalin's regime. Public squares, an overview of the city, street-space, vast recreational areas and newly built industrial zones are at the centre of urban representation. However, living space is not cinematic and portrayal of both the Soviet apartments and residential housing is limited. Also, other geographical and functional structures are mostly abandoned, such as public services or neglected space. It confirms the tendency of Soviet cinema to refuse the representation of imperfect space.

\section{Kopsavilkums}

Par telpas vizuālo reprezentāciju tiek uzskatìts attēls, kurā ir ietverts ierobežots vēstījuma kopums, savukārt filmas nav nejaušs attēlu atveids, bet gan pārdomāts pilsētvidē pastāvošo sociālo, ekonomisko un politisko procesu raksturojums. Kultūras geogrāfija tiecas pilsētas attēlus un tajā notiekošos procesus raksturot kā daḷu no kultūras ainavas. Pilsētvides reprezentācija filmās ir viena no nozīmīgākajām pieejamajām kultūras geogrāfijā, sniedzot pētniekiem iespēju skaidrot pilsētu ar paņēmieniem, kādus nepiedāvā tradicionālās dabas un sociālās zinātnes. 
Raksta mērḳis ir izzināt Rīgas dzīvojamo telpu diskursu Staļina laika kinematogrāfijā laika periodā no 1945. līdz 1953. gadam. Atsevišķas, ar nodomu izvēlētas, kinematogrāfiskās metodes tiek lietotas padomju filmās, dzīvojamo platību atklājot kā politiski pārvaldītu telpu ar skaidri raksturotām telpiskām funkcijām un iedzīvotāju kategorijām, kurām šo telpu ir atḷauts apdzīvot. Pētījums ietver 276 dokumentālo un spēlfilmu analīzi. Rīgā uzṇemto filmu saraksts pētījuma veikšanai tika iegūts, izmantojot Nacionālā Kino centra datu bāzi.

Lai novērtētu padomju kinematogrāfisko materiālu, tika izmantota A. R. Hazana filmu pētījuma metode, katru filmu sadalot piecu minūšu intervālos. Katrs no apskatītajiem filmas intervāliem tika raksturots pēc astoṇiem iepriekš noteiktiem indikatoriem: atveidotā objekta atrašanās vietas, cilvēku skaita, iekštelpas iekārtojuma, publiskās un semi-publiskās telpas atveida, mise-en-scène, runātā teksta un filmēšanas tehnikas. Šis pētījums izskaidro paṇēmienu kopumu, kādā dz̄ivojamā telpa tika atveidota Stalina laika kino. Pētījumā apskatītās filmas tika iedalītas 12 kategorijās pēc to geogrāfiskās un funkcionālās struktūras, noškirot dabas objektus, atpūtas vietas, inženierbūves, dzīvojamos rajonus un citas struktūras. Kopā 601 telpiskais punkts tika identificēts un izmantots pētījuma kartogrāfiskā materiāla izveidē.

No 20. gadsimta 40. gadu vidus līdz 50. gadu vidum galvenās filmās atveidotās telpiskās struktūras ir Vecrīga un Rīgas centrs. Ārpus pilsētas centra tiek atveidotas industriālās būves un rekreācijas zonas, tādējādi veidojot utopisku pilsētas telpas atveidu: nevainojamu un visiem pieejamu publisko telpu līdzās ar platībā strauji augošajiem Rīgas industriālajiem rajoniem.

Pretstatā publiskajai telpai, privātās telpas atveids Staḷina laika filmās ir ierobežots. Šì perioda spēlfilmās tiek atveidotas lauku un Rīgas centra dzīvojamās telpas, atklājot kara radītās sekas un veidojot atsauci uz starpkaru perioda greznajām iekštelpām, turpretim dokumentālās filmas atklāj monofunkcionālu interjeru, uzman̄̄bu vēršot uz ǵimenes ēdamgaldu viesistabā (stolovaja). Pētījums atklāj, ka Stalina laika pilsētas telpa kinematogrāfijā tiek atveidota bieži, tādējādi kḷūstot par nozīmīgu filmās atveidotā stāstījuma struktūru. Lai gan Stalina laika filmas lielā mērā atveido Rīgas centrālo dalıu un ārpus tās esošos publiskos laukumus, atpūtas un industriālās zonas, tomēr dz̄̄vojamā telpa nav kinematogrāfiskā atveida centrālā vienība, padomju dzīvoklis atveidots tikai 11 pētītajās filmās.

\section{References.}

Bodenschatz, H. (2014). Urban design for Mussolini, Stalin, Salazar, Hitler and Franco (19221945). Planning Perspectives, 29 (3), 381-392.

Bunkše, E.V. (1979). The role of a human environment in Soviet urban planning. Geographical Review, 69 (4), 379-394.

Čardina, M. (1948). Padomju Latvija Nr. 16 [fiction movie]. http://www.redzidzirdilatviju.lv/lv/search/movie/160566?filter=date_from:1948;date_to:1948 (1.01.2019).

Fedorov, A. (2015). The mass and individual terror in the mirror of the Soviet and Russian cinema (the feature films of the sound period) and media literacy education. European Research. 101 (12), 778-771.

French, R.A. (1995). Plans, pragmatism and people: the legacy of Soviet planning for today's cities. London: UCL Press, 62-152.

Gentile, M. and Sjöberg, Ö. (2006). Intra-urban landscapes of priority: the Soviet legacy. Europe-Asia Studies. 58 (5), 701-729.

Gentile, M. and Sjöberg, Ö. (2010). Space of priority: The geography of Soviet housing construction in Daugavpils, Latvia. Annals of the Association of American Geographers, 100 (1), 112-136.

Goldberga, No. (1946). Padomju Latvija Nr. 47 [fiction movie]. http://www.redzidzirdilatviju.lv/lv/search/movie/160458?filter=date_from:1946; date_to:1946 (4.01.2019).

Grava, S. (2007). The urban heritage of the Soviet regime: the case of Riga Latvia. Journal of the American Planning Association, 59 (1), 9-22.

Hazan, A.R., Lipton, H.L. and Glantz, S.A. (1994). Popular films do not reflect current tobacco use. American Journal of Public Health, 84, 998-1000. 
Hurina, A. (2015). Representations of Urban Spaces and Their Transformations in Soviet Cinema of the 1920s and 1960s. Durham: Durham University.

Ivanovs, A. (1946). Dēli [fiction movie]. https:/www.youtube.com/watch?v=nxiulDXTtmc (12.12.2018).

Ivanovs, A. (1946). Mājup ar uzvaru [fiction movie]. https://www.youtube.com/watch?v=wU5mjLMKxDo (5.01.2019).

Jevsikovs, A. (1951). Padomju Latvija Nr. 17 [fiction movie]. http://www.redzidzirdilatviju.lv/lv/search/movie/161199?filter=date_from:1951; date_to:1951 (8.01.2019).

Kennedy, C. and Lukinbeal, C. (1997). Towards a holistic approach to geographic research on film. Progress in Human Geography, 21 (1), 33-50.

Lukinbeal, C. (2005). Cinematic landscapes. Journal of Cultural Geography, 23 (1), 3-22.

Lukinbeal, C. (2012). "On location" filming in San Diego county from 1985-2005: How a cinematic landscape is formed through incorporative tasks and represented through mapped inscriptions. Annals of the Association of American Geographers. 102 (1), 171-190.

Matvejs, J. (2017). Visual representation of urban environment: Microraioni of Riga in Soviet cinematography. Architecture and Urban Planning, 13, 54-60.

Mazierska, E. (2014). Squeezing space, releasing space: spatial research in the study of Eastern European cinema. In: Bahun, S., Haynes, J. (eds.) Cinema, State Socialism and Society in the Soviet Union and Eastern Europe, 1917-1989: Re-visions. New York: Routledge.

Näripea, E. (2004). Medieval socialist realism: Representations of Tallinn Old Town in Soviet Estonian feature films, 1969-1972. Spec. issue of Place and Location: Studies in Environmental Aesthetics and Semiotics IV, 121-144.

Nuga, M. (2016). Soviet-era summerhouses. On homes and planning in post-socialist suburbia. Tartu: Tartu University Press.

Prokhorov, A. (2001). Springtime for Soviet Cinema. Re/Viewing the 1960s. Pittsburgh: Russian Film Symposium.

Reid, S. (2006). Khrushchev modern: Agency and modernization in the Soviet home. Cahiers Du Monde Russe. 47 (1), 227-258.

Reid, S. (2009). Communist comfort: Socialist modernism and the making of cosy homes in the Khrushchev era. Gender \& History. 21 (3), 465-498.

Richardson, W. H. (2010). Planning a model Soviet city: Transforming Vladivostok under Stalin and Brezhnev. Urban Transformation: Controversies, Contrasts and Challenges. Paper of 14th IPHS Conference.

Rudovska, M. (2012). Expired monuments: Case studies on Soviet-era architecture through the kaleidoscope of postcolonialism. Kunstiteaduslikke Uurimusi, 32 (3/4), 77-80.

Šulatins, H. (1952). Padomju Latvija Nr. 41 [fiction movie]. http://www.redzidzirdilatviju.lv/lv/search/movie/161446?filter=date_from:1952;date_to:1952 (1.01.2019)

Varga-Harris, C. (2008). Homemaking and the aesthetic and moral perimeters of the Soviet home during the Khrushchev era. Journal of Social History, 41 (3), 561-589.

Varga-Harris, C. (2015). Stories of House and Home: Soviet Apartment Life During the Khruschev Years. New York: Cornell University Press. 